\title{
Luteirhabdus pelagi gen. nov., sp. nov., a novel member of the family Flavobacteriaceae, isolated from the West Pacific Ocean
}

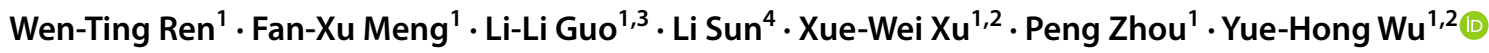

Received: 26 March 2021 / Revised: 23 August 2021 / Accepted: 26 August 2021 / Published online: 26 October 2021

(c) The Author(s) 2021

\begin{abstract}
A Gram-stain-negative, aerobic, and yellow-pigmented bacterium, designated A3-108 ${ }^{\mathrm{T}}$, was isolated from seawater of the West Pacific Ocean. Cells were non-motile and rod-shaped, with carotenoid-type pigments. Strain A3-108 ${ }^{\mathrm{T}}$ grew at $\mathrm{pH}$ 6.0-8.5 (optimum 6.5) and $15-40{ }^{\circ} \mathrm{C}$ (optimum $28^{\circ} \mathrm{C}$ ), in the presence of $0.5-10 \%(\mathrm{w} / \mathrm{v}) \mathrm{NaCl}$ (optimum 1.0\%). It possessed the ability to produce $\mathrm{H}_{2} \mathrm{~S}$. Based on the $16 \mathrm{~S}$ rRNA gene analysis, strain A3-108 ${ }^{\mathrm{T}}$ exhibited highest similarity with Aureisphaera salina $\mathrm{A} 6 \mathrm{D}-50^{\mathrm{T}}$ (90.6\%). Phylogenetic analysis shown that strain $\mathrm{A} 3-108^{\mathrm{T}}$ affiliated with members of the family Flavobacteriaceae and represented an independent lineage. The principal fatty acids were iso- $\mathrm{C}_{15: 0}$, iso- $\mathrm{C}_{17: 0} 3-\mathrm{OH}$, iso- $\mathrm{C}_{15: 1}$ $\mathrm{G}$, and summed feature $3\left(\mathrm{C}_{16: 1} \omega 7 c\right.$ and/or $\left.\mathrm{C}_{16: 1} \omega 6 c\right)$. The sole isoprenoid quinone was MK-6. The major polar lipids were phosphatidylethanolamine, one unidentified aminophospholipid, one unidentified aminolipid and one unidentified lipid. The ANIb, in silico DDH and AAI values among the genomes of strain A3-108 ${ }^{\mathrm{T}}$ and three reference strains were $67.3-71.1 \%$, 18.7-22.1\%, and 58.8-71.4\%, respectively. The G+C content was $41.0 \%$. Distinctness of the phylogenetic position as well as differentiating chemotaxonomic and other phenotypic traits revealed that strain A3-108 ${ }^{\mathrm{T}}$ represented a novel genus and species of the family Flavobacteriaceae, for which the name Luteirhabdus pelagi gen. nov., sp. nov. is proposed (type strain, A3 $-108^{\mathrm{T}}=$ CGMCC $1.18821^{\mathrm{T}}=$ KCTC $\left.82563^{\mathrm{T}}\right)$.
\end{abstract}

Keywords Luteirhabdus $\cdot$ Flavobacteriaceae $\cdot$ Bacteroidetes $\cdot$ Phylogenetic analysis $\cdot$ West Pacific Ocean · Genomic analysis

\begin{tabular}{|c|c|c|c|}
\hline & & Abbreviation & \\
\hline & & AAI & Average amino acid identity \\
\hline & & ANI & Average nucleotide identity \\
\hline Con & mmunicated by Erko Stackebrandt. & ANIb & $\begin{array}{l}\text { Average nucleotide identity based on } \\
\text { BLAST }\end{array}$ \\
\hline$M$ & Peng Zhoul & $\mathrm{DDH}$ & DNA-DNA hybridization \\
\hline & hockeyextremophiles@yahoo.com & MA & Marine agar 2216 \\
\hline$\triangle$ & Yue-Hong Wu & MB & Marine broth 2216 \\
\hline$\Delta$ & yuehongwu@sio.org.cn & MOF medium & Marine oxidation-fermentation medium \\
\hline & & ML & Maximum-likelihood \\
\hline 1 & Key Laboratory of Marine Ecosystem Dynamics, Ministry & MP & Maximum parsimony \\
\hline & $\begin{array}{l}\text { of Natural Resources \& Second Institute of Oceanography, } \\
\text { Ministry of Natural Resources, Hangzhou } 310012 \text {. }\end{array}$ & NJ & Neighbor-joining \\
\hline & People's Republic of China & MK-6 & Menaquinone-6 \\
\hline 2 & School of Oceanography, Shanghai Jiao Tong University, & APL & Aminophospholipid \\
\hline & Shanghai 200240, People's Republic of China & AGL & Aminoglycolipid \\
\hline 3 & College of Life and Environmental Science, Hunan & $\mathrm{PE}$ & Phosphatidylethanolamine \\
\hline & University of Arts and Science, Changde 415000 , & $\mathrm{AL}$ & Unidentified aminolipid \\
\hline & People's Republic of China & GL & Unidentified glycolipid \\
\hline 4 & State Research Center of Island Exploitation & $\mathrm{L}$ & Unidentified lipid \\
\hline
\end{tabular}




\section{Introduction}

The family Flavobacteriaceae, belonging to the class Flavobacteriia, the phylum Bacteroidetes, was first proposed by Jooste (1985), validly published by Reichenbach (1992), then emended by Bernardet et al. (1996, 2002) and García-López et al. (2019). Prior to 2021, the family Flavobacteriaceae comprised 150 genera with validly published names. This study focuses on the description of a novel genus and species with the type strain A3-108 ${ }^{\mathrm{T}}$ was isolated from seawater collected at the seamount area in the West Pacific Ocean.

Seamounts are defined as the huge uplifts located below sea level, and exceed $1000 \mathrm{~m}$ in height, and are unique environments widely distributed on the deep-ocean subseafloor (Yesson et al. 2011). The West Pacific Ocean has the most concentrated area of global seamount systems (Qin and Yin 2011). Seamounts are important habitats for marine organisms (Clark et al. 2010). In the upper water column, primary productivity is influenced by topographically induced turbulent mixing in the seamounts' ecosystem (Boehlert and Genin 1987; Polzin et al. 1997), which has a strong impact on physical/chemical parameters and organism communities (Mashayek et al. 2017; Muck et al. 2014). Currently, there are few studies on microbial communities in seamount environments.

\section{Materials and methods}

\section{Samples and isolation}

During the investigation of bacterial diversity, a seawater sample from the seamount area in the West Pacific Ocean (at a depth of $300 \mathrm{~m}, 23.2^{\circ} \mathrm{N}, 162.3^{\circ} \mathrm{E}$ ), was collected by a rosette sampler connected with CTD system (SBE911 plus; Sea-Bird Electronics, Inc. USA) in 2018. Aboard the ship, the seawater sample was subjected to the culture process immediately. Approximately $100 \mu \mathrm{L}$ seawater samples were diluted using serial dilution technique and added to different media. The strain $\mathrm{A} 3-108^{\mathrm{T}}$ was isolated aerobically on natural seawater agar $(1 \mathrm{~L}$ filtered natural seawater supplemented with $0.5 \mathrm{~g}$ peptone (BD Difco), $0.1 \mathrm{~g}$ yeast extract (BD Difco), $20 \mathrm{~g}$ agar (BD Difco), $\mathrm{pH}$ 7.2-7.4) and purified by repeated restreaking. The purity was confirmed by the uniformity of cell morphology. Unless otherwise stated, strain A3-108 ${ }^{\mathrm{T}}$ was routinely cultured in marine broth 2216 (MB, BD Difco) or on marine agar 2216 (MA, BD Difco) at $30{ }^{\circ} \mathrm{C}$ and maintained at $-80{ }^{\circ} \mathrm{C}$ with $30 \%$ (v/v) glycerol. Galbibacter mesophilus CGMCC $1.15663^{\mathrm{T}}$ and Marixanthomonas ophiurae JCM $14121^{\mathrm{T}}$, were obtained from the CGMCC (China General
Microbiological Culture Collection Center) and JCM (Japan Collection of Microorganisms), respectively. An additional reference strain Marinirhabdus gelatinilytica $\mathrm{NH} 83^{\mathrm{T}}$ was obtained from our laboratory (Wu et al. 2016).

\section{S rRNA gene and genome sequence determination}

High-quality genomic DNA was extracted by Nucleic Acid Purification kit (Dongsheng Biotech). The 16S rRNA gene was amplified by the universal primers 27F/1492R (27F: 5'-AGAGTTTGATCCTGGCTCAG-3'; 1492R: 5'-GGYTAC CTTGTTACGACTT-3'). The PCR thermal cycling conditions were as follows: 30 cycles of $98{ }^{\circ} \mathrm{C}$ for $10 \mathrm{~s}, 55^{\circ} \mathrm{C}$ for $10 \mathrm{~s}$, and $72{ }^{\circ} \mathrm{C}$ for $30 \mathrm{~s}$. The PCR products were purified and sequenced by Sanger sequencing to obtain the almost complete 16S rRNA gene sequence.

The genomic DNA of strain A3-108 ${ }^{\mathrm{T}}$ and Galbibacter mesophilus CGMCC $1.15663^{\mathrm{T}}$ were sequenced by Solexa paired-end sequencing technology with the Illumina NovaSeq 6000 PE150 platform (Novogene Co. Ltd, Tianjing). One paired-end library was constructed with insert size of $350 \mathrm{bp}$. The sequencing generated approx. $1 \mathrm{~Gb}$ clean data (approx. 500-fold genome coverage). De novo assembly of the reads was carried out using SOAPdenovo (version 2.0.1) (Luo et al. 2012). The completeness of genome sequences was addressed using the bioinformatics tool CheckM (http://ecogenomics.github.io/CheckM/) (Parks et al. 2015). The complete 16S rRNA gene was annotated via the RNAmmer 1.2 Server (Lagesen et al. 2007) and compared with gene sequences obtained from PCR to ensure its authenticity.

\section{Phylogenetic status and DNA relatedness}

The 16S rRNA gene sequence was compared with the corresponding sequences of closely related organisms via online EzBioCloud service (https://www.ezbiocloud.net) (Yoon et al. 2017). Based on 16S rRNA gene similarity, 23 species were selected and aligned for phylogenetic analysis by CLUSTALW software (Thomson et al. 1994). Phylogenetic trees were constructed using MEGA 7.0 program package (Kumar et al. 2016) using the methods of neighbor-joining (Saitou and Nei 1987), maximum-parsimony (Fitch 1971) and maximum-likelihood (Felsenstein 1981). Evolutionary distances of the neighborjoining method were calculated according to the Kimura-2-parameter algorithm model (Kimura 1980).

A phylogenomic tree was constructed based on singlecopy orthologous clusters (OCs) of strain A3-108 ${ }^{\mathrm{T}}$ and its related taxa of the family Flavobacteriaceae. The related genome sequences were obtained from the NCBI GenBank database and annotated using the Prokka server (Seemann 2014). Orthologous clusters (OCs) were selected by 
Proteinortho (version 5.16b) (Lechner et al. 2014). Singlecopy OCs were filtered by an in-house shell script. Protein sequences were aligned using MAFFT (version 7) (Katoh and Standley 2013). Aligned sequences were refined via trimAL (version 1.4.1) (Capella-Gutiérrez et al. 2009) and concatenated by an in-house shell script. The best substitution model was estimated by IQ-Tree software (version 1.6.1) (Nguyen et al. 2015) and the model $L G+F+R 4$ was selected. The maximum-likelihood phylogenomic tree was reconstructed through IQ-Tree software and visualized applying MEGA 7.0 software (Kumar et al. 2016).

The average nucleotide identity (ANI) values, the DNA-DNA hybridization (DDH) values and the average amino acid identity (AAI) values were calculated using JSpeciesWS (http://jspecies.ribohost.com/jspeciesws/), Genome-to-Genome Distance Calculator (GGDC; version 2.1) (https://ggdc.dsmz.de/home.php) and AAI calculator (http://enve-omics.ce.gatech.edu/aai/), respectively (Richter et al. 2016; Meier-Kolthoff et al. 2013; Luis et al. 2014). Orthologous average nucleotide identity (OrthoANI) values were calculated by OAT (Chun et al. 2016).

\section{Phenotypic characteristics}

Cell morphology, ultrastructure, size, and the presence of flagellum were observed by transmission electron micrographs (JEM-1230, JEOL). Gram reaction was determined by the Gram-Stain method (Brown and Hopps 1973). Motility was examined by stab culture with semi-solid medium, using MB supplemented with $0.5 \%$ (w/v) agar (Wolfe and Berg 1989). The temperature range for growth was investigated by incubating in $\mathrm{MB}$ at 4, 15, 20, 28, 30, 37, 40, 45, and $50^{\circ} \mathrm{C}$. The $\mathrm{pH}$ range for growth was determined in $\mathrm{MB}$ with different $\mathrm{pH}$ ( $\mathrm{pH} 5.0-10.5$, in $0.5 \mathrm{pH}$ unit intervals) using appropriate biological buffers at $50 \mathrm{mM}$ concentration (MES for $\mathrm{pH}$ 5.0-6.0, PIPES for $\mathrm{pH}$ 6.5-7.0, Tricine for $\mathrm{pH}$ 7.5-8.5, CAPSO for $\mathrm{pH} 9.0-10.0$ and CAPS for $\mathrm{pH} 10.5$ ). The optimal conditions with $\mathrm{NaCl}$ for growth were measured using $\mathrm{NaCl}$-free $\mathrm{MB}$ (prepared according to the MB formula, but without $\mathrm{NaCl}$ ) with different $\mathrm{NaCl}$ concentrations $(0$, $0.5,1.0,3.0,5.0,7.5,10.0,15.0,20.0$, and $25 \%$, w/v). Cell densities were monitored by measuring with a UV/Visible Spectrophotometer at $600 \mathrm{~nm}$ (Ultrospec 6300 pro; Amersham Biosciences). Anaerobic growth was tested by the Anaero-Pack (Mitsubishi) adding sodium nitrate $(10 \mathrm{mM})$, sodium sulfate $(10 \mathrm{mM})$, and sodium thiosulfate $(10 \mathrm{mM})$ as potential electron acceptors on the MA. The growth curve of strain $\mathrm{A} 3-108^{\mathrm{T}}$ was determined by incubation in $\mathrm{MB}$ with the optimal growth condition $\left(30^{\circ} \mathrm{C}, 180 \mathrm{rpm}\right)$, and cell densities were measured every $2 \mathrm{~h}$ incubation via measuring $\mathrm{OD}_{600}$ in a UV/Visible Spectrophotometer (Genesys 50; Thermofisher Scientific). The doubling time and the specific growth rate were calculated by formulas: doubling time $\left(t_{d} / \mathrm{h}\right)=\ln 2 / k$; specific growth rate $(\mu /$ $\left.\mathrm{h}^{-1}\right)=1 / t_{d}$;

$k$ represents relative growth rate (slope of the curve) (Monod 1949).

Flexirubin-type pigments were detected by a bathochromic shift test (Fautz and Reichenbach 1980). Carotenoidtype pigments were detected by pigment absorption spectrum analysis as described by Hildebrand et al. (1994). Pigments were extracted with acetone/methanol $(7: 2, \mathrm{v} / \mathrm{v})$ and performed by a Beckman DU 800 Spectrophotometer (detection wavelength from 300 to $800 \mathrm{~nm}$ ).

Oxidase and catalase activities, $\mathrm{H}_{2} \mathrm{~S}$ production from sodium thiosulfate $(0.5 \%, \mathrm{w} / \mathrm{v})$, sodium sulfate $(0.5 \%, \mathrm{w} / \mathrm{v})$, and cysteine $(0.5 \%, \mathrm{w} / \mathrm{v})$ and the hydrolysis abilities of starch $(0.2 \%, \mathrm{w} / \mathrm{v})$, DNA $((0.2 \%, \mathrm{w} / \mathrm{v}))$, L-tyrosine $(0.5 \%$, $\mathrm{w} / \mathrm{v})$, esculin $(0.1 \%, \mathrm{w} / \mathrm{v}), \mathrm{CM}$-cellulose $(1.0 \%, \mathrm{w} / \mathrm{v})$, and Tween $40(1.0 \%, \mathrm{w} / \mathrm{v}), 60(1.0 \%, \mathrm{w} / \mathrm{v})$, and $80(1.0 \%$, w/v) were determined as previously described (Dong and Cai 2001). Acid production was examined by MOF medium supplemented with $0.5 \%$ alcohols or sugars (Leifson 1963). The activities of enzymes, including nitrate reduction and assimilation carbohydrates, were tested by API ZYM and API 20NE tests (bioMérieux) at $30{ }^{\circ} \mathrm{C}$. API ZYM strips were read after $24 \mathrm{~h}$ and API 20NE strips were read after $48 \mathrm{~h}$, according to the manufacturer's instructions. Three reference strains, Marinirhabdus gelatinilytica $\mathrm{NH}^{2} 3^{\mathrm{T}}$, Galbibacter mesophilus CGMCC $1.15663^{\mathrm{T}}$ and Marixanthomonas ophiurae $\mathrm{JCM} 14121^{\mathrm{T}}$, were used as controls in the above tests.

\section{Chemotaxonomic analysis}

The cellular fatty acids of the strain A3-108 ${ }^{\mathrm{T}}$ and three reference strains were determined under identical conditions in parallel. Approximately $20 \mathrm{mg}$ of cells were harvested by the quadrant streak method on MA plates at $30{ }^{\circ} \mathrm{C}$ for 3 days (quadrant 3 exhibiting confluent growth). Fatty acids were extracted by saponification, methylation, and extraction as described previously (Sasser 1990). The cellular fatty acids were analyzed by 6890 gas chromatograph according to Microbial Identification System (MIDI).

For polar lipids and isoprenoid quinones analyses, strain A3- $108^{\mathrm{T}}$ was cultivated in $\mathrm{MB}$ at $30^{\circ} \mathrm{C}$ for 3 days to obtain cell biomass. Respiratory quinones were extracted from cells (around $200 \mathrm{mg}$ ) with chloroform/methanol $(2: 1, \mathrm{v} / \mathrm{v})$ and analyzed by LC-MS (Agilent) (Komagata and Susuki 1987). Polar lipids were extracted and separated by twodimensional TLC (Tindall et al. 2007), with chloroform/ methanol/water $(13: 5: 0.8, \mathrm{v} / \mathrm{v})$ for the first direction and chloroform/methanol/acetic/water (16:2.4:3:0.8, v/v) for the second direction. Total lipids, aminolipids, phospholipids, and glycolipids were detected by molybdatophosphoric acid, $0.5 \%$ ninhydrin reagent, Molybdenum Blue spray reagent 


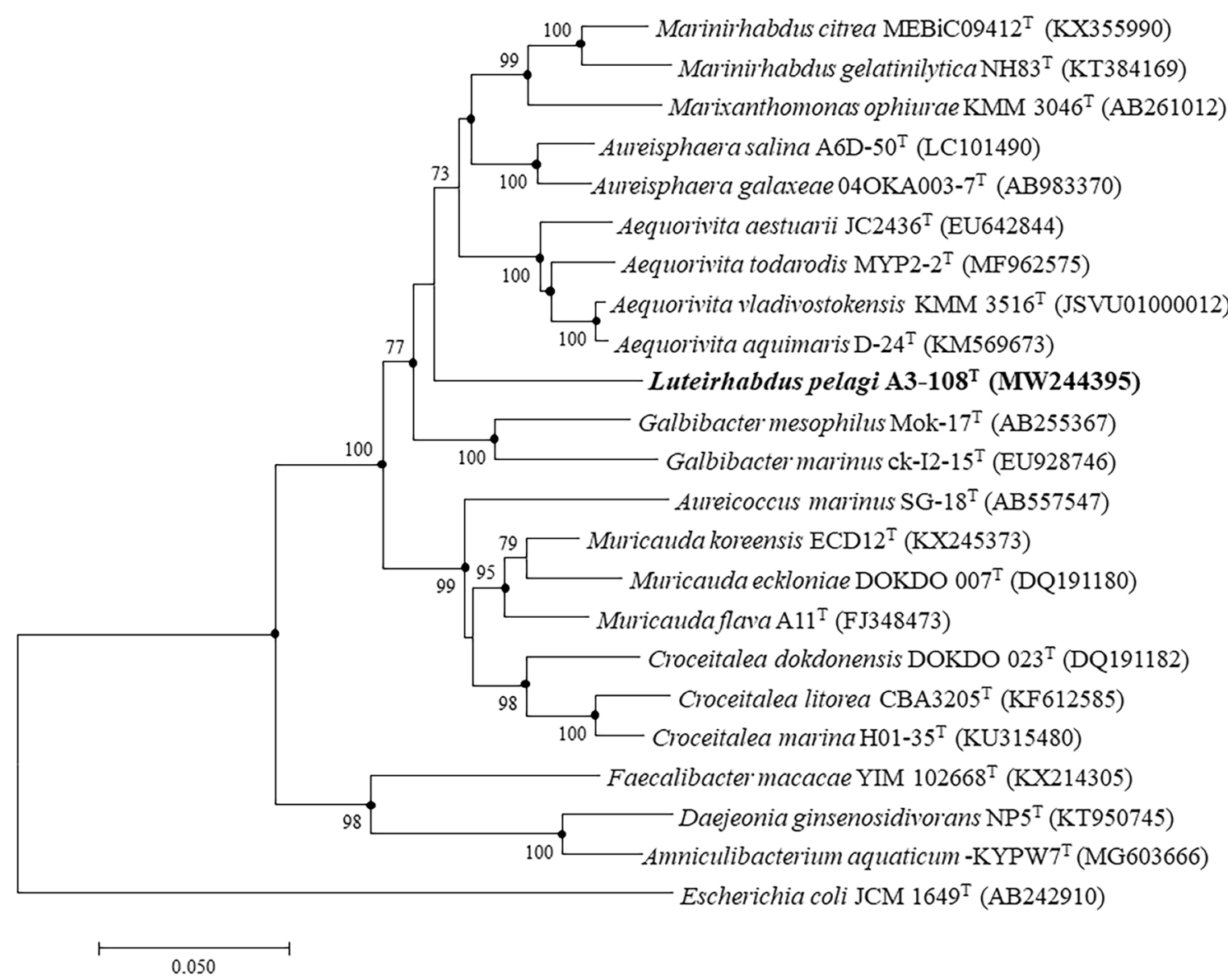

Fig. 1 Neighbor-joining phylogenetic tree based on 16S rRNA gene sequences showing the phylogenetic relationships of the strain $\mathrm{A} 3-108^{\mathrm{T}}$ and related taxa. Bootstrap values (expressed as percentages of 1000 replications) of $70 \%$ or more are shown at branch nodes.

(SIGMA), and 0.5\% $\alpha$-naphthol reagent with methanol/water $(1: 1, \mathrm{v} / \mathrm{v})$, respectively (Komagata and Susuki 1987).

\section{Genomic analysis}

The draft genome sequence was annotated using the RAST server online (https://rast.nmpdr.org/rast.cgi) (Aziz et al. 2008), and annotation information including predicted coding sequences (CDSs), proteins and RNAs were obtained. Metabolic pathways were predicted using the Kyoto Encyclopedia of Genes and Genomes (KEGG) online annotation server (Kanehisa et al. 2016).

\section{Results and discussion}

\section{S rRNA gene sequence similarities and phylogenetic analysis}

The almost complete 16S rRNA gene sequence of strain A3-108 ${ }^{\mathrm{T}}$ was obtained. According to the results of EzBioCloud, the strain
Filled circles indicate that the corresponding nodes were also recovered in the trees generated with the maximum-likelihood and maximum-parsimony algorithms. Bar, 0.05 substitutions per nucleotide position

A3-108 ${ }^{\mathrm{T}}$ was closely related to members of the family Flavobacteriaceae and its $16 \mathrm{~S}$ rRNA gene sequence showed the highest similarity to Aureisphaera salina A6D-50 ${ }^{\mathrm{T}}(90.6 \%)$, followed by Galbibacter mesophilus Mok-17 $7^{\mathrm{T}}$ (90.5\%), Marinirhabdus gelatinilytica $\mathrm{NH} 83^{\mathrm{T}}(90.4 \%)$, Aureisphaera galaxeae 04OKA003- $7^{\mathrm{T}}$ (90.4\%) and Aequorivita aestuarii JC2436 ${ }^{\mathrm{T}}$ (90.2\%).

The phylogenetic trees manifested that strain $\mathrm{A} 3-108^{\mathrm{T}}$ fall into the family Flavobacteriaceae and formed a separated branch apart from other genera of the family with high bootstrap values (Fig. 1). Phylogenetic analysis indicated that the strain $\mathrm{A} 3-108^{\mathrm{T}}$ represented an independent lineage in family Flavobacteriaceae. Furthermore, the maximum-likelihood phylogenomic tree based on single-copy orthologous clusters (OCs) demonstrated that strain A3-108 ${ }^{\mathrm{T}}$ affiliated with the family Flavobacteriaceae and clustered with Marixanthomonas ophiurae $\mathrm{KMM} 3046^{\mathrm{T}}$ (Fig. 2).

\section{Genomic features and DNA-DNA relatedness}

Based on the bioinformatic tool CheckM, the genome completeness of strain $\mathrm{A} 3-108^{\mathrm{T}}$ was $99.2 \%$, with $0.27 \%$ 


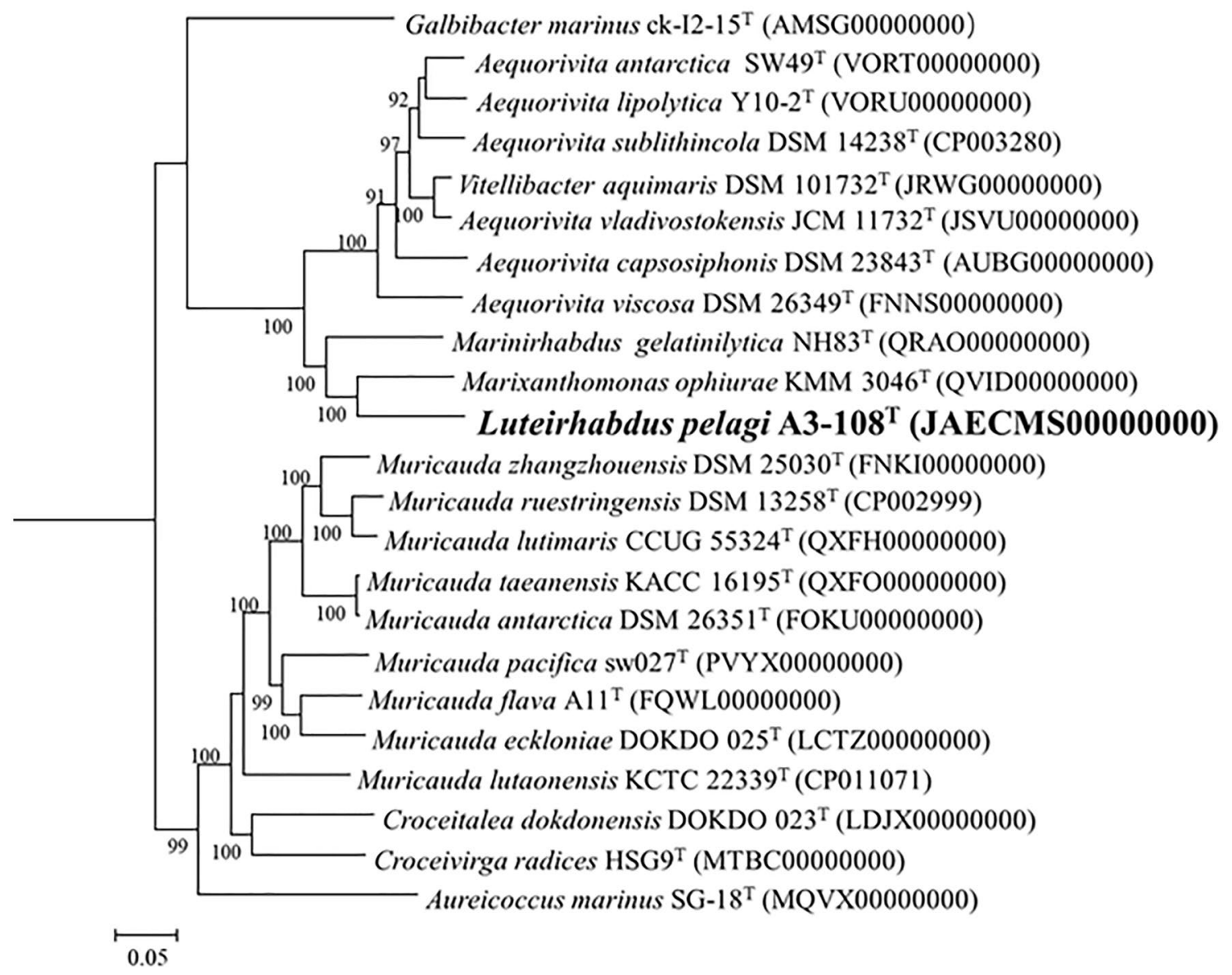

Fig. 2 Phylogenomic tree based on the genomic sequences reflecting the phylogenetic relationship of the strain $\mathrm{A} 3-108^{\mathrm{T}}$ and the related taxa. Bootstrap values $(>90 \%)$ based on 100 replications are shown at brand nodes. Escherichia coli $\mathrm{K}-12^{\mathrm{T}}$ (GenBank assembly accession

contamination. The genome sequence estimated to be $\geq 95 \%$ completeness, with $\leq 5 \%$ contamination, was considered to be an excellent reference genome for deeper analyses (Pruesse et al. 2007). The final genome of strain A3-108 ${ }^{\mathrm{T}}$ comprised a total size of $3.40 \mathrm{Mb}$ with 99 contigs, and $\mathrm{G}+\mathrm{C}$ content was $41.0 \%$. The assembled scaffolds annotated by RAST online, harbored a total of 3250 coding genes, 37 tRNAs and 5 rRNAs. The general genomic features of strain A3-108 ${ }^{\mathrm{T}}$ and reference strains are shown in Supplementary Table S1. The ANIb and in silico DDH among the genome of strain $\mathrm{A} 3-108^{\mathrm{T}}$ and the reference strains were $67.3-71.1 \%$ and $18.7-22.1 \%$, respectively (Supplementary Table S2). The ANI values were far below the species threshold of 94-96\% (Richter and Rosselló-Móra 2009) and the genus demarcation boundary of $90 \%$ (Barco et al. 2020). The in silico DDH values were below the threshold value $70 \%$ that corresponded to the species boundary (Wayne et al. 1987). In addition, the AAI values were $58.8-71.4 \%$ among the genome of strain $\mathrm{A} 3-108^{\mathrm{T}}$ and the reference number is GCA_000005845.2) was used as outgroup (not shown in the phylogenetic tree). Bar, 0.05 substitutions per genomic sequence position

strains (Supplementary Table S2), which were below the species cutoff 95-96\% (Konstantinidis and Tiedje 2005) and the threshold of $60-80 \%$ to distinguish genera from each other (Luo et al. 2014). The OrthoANI values between strain $\mathrm{A} 3-108^{\mathrm{T}}$ and the reference strains were $67.7-71.5 \%$ (Supplementary Table S2). The ANI, in silico DDH and AAI values indicted a low taxonomic relatedness between strain $\mathrm{A} 3-108^{\mathrm{T}}$ and the reference strains of the family Flavobacteriaceae.

\section{Phenotypic features}

Strain A3-108 ${ }^{\mathrm{T}}$ was Gram-stain-negative, aerobic, nonmotile, and rod-shaped with $0.5-0.8 \mu \mathrm{m}$ in width and $1.6-3.9 \mu \mathrm{m}$ in length (Supplementary Fig. S1). No flagellum was observed. Colonies were yellow, circular, convex, opaque, smooth, and 1-2 $\mathrm{mm}$ in diameter after 3 days of incubation at $30{ }^{\circ} \mathrm{C}$ on MA. The growth range of $\mathrm{pH}$, temperature and $\mathrm{NaCl}$ concentrations were $\mathrm{pH}$ 6.0-8.5, 
Table 1 Differential phenotypic characteristics among strain A3 $-108^{\mathrm{T}}$ and its related taxa

\begin{tabular}{|c|c|c|c|c|}
\hline Characteristics & 1 & 2 & 3 & 4 \\
\hline \multicolumn{5}{|l|}{ Growth in $\mathrm{NaCl}(\%, w / v)$ : } \\
\hline Range & $0.5-10$ & $0.5-7.5^{*}$ & $3.0-7.0^{\dagger}$ & $1.0-12.0^{\ddagger}$ \\
\hline Optimum & 1.0 & $2.0-5.0^{*}$ & $3.0-5.0^{\dagger}$ & $3.0-5.0^{\ddagger}$ \\
\hline \multicolumn{5}{|l|}{ Growth in $\mathrm{pH}$ : } \\
\hline Range & $6.0-8.5$ & $6.5-7.5^{*}$ & $--^{\dagger}$ & $-\ddagger$ \\
\hline Optimum & 6.5 & $7.0^{*}$ & $--^{\dagger}$ & $6.5-8.5^{\ddagger}$ \\
\hline \multicolumn{5}{|l|}{ Growth temperature $\left({ }^{\circ} \mathrm{C}\right)$ : } \\
\hline Range & $15-40$ & $4-37 *$ & $10-42^{\dagger}$ & $5-32^{\ddagger}$ \\
\hline Optimum & 28 & $30^{*}$ & $25-30^{\dagger}$ & $25-28^{\ddagger}$ \\
\hline Nitrate reduction & - & - & + & - \\
\hline \multicolumn{5}{|l|}{ Hydrolysis of } \\
\hline Catalase & - & + & + & + \\
\hline Esculin & - & - & + & - \\
\hline L-Tryosine & - & - & + & - \\
\hline Tween 60 & - & - & + & + \\
\hline API ZYM system & - & & & \\
\hline$N$-Acetyl- $\beta$-glucosaminidase & - & - & + & - \\
\hline$\alpha$-Galactosidase & - & - & + & - \\
\hline$\beta$-Galactosidase & - & - & + & - \\
\hline$\alpha$-Glucosidase & - & - & + & - \\
\hline$\beta$-Glucosidase & - & - & + & - \\
\hline \multicolumn{5}{|l|}{ API 20NE system } \\
\hline Arginine dihydrolase & + & - & - & - \\
\hline Assimilation D-glucose & - & - & + & - \\
\hline Assimilation D-mannose & - & - & + & - \\
\hline Assimilation D-maltose & - & - & + & - \\
\hline Hydrolysis ( $\beta$-glucosidase) esculin & - & - & + & - \\
\hline $\begin{array}{l}\beta \text {-Galactosidase (para-nitrophenyl- } \beta \text {-D- } \\
\text { galactopyranosidase) }\end{array}$ & - & - & + & - \\
\hline \multicolumn{5}{|l|}{ Acid production from } \\
\hline D-Cellobiose & - & - & + & - \\
\hline D-Galactose & - & - & + & - \\
\hline D-Maltose & - & - & + & - \\
\hline D-Salicin & - & - & + & - \\
\hline D-Trehalose & - & - & + & - \\
\hline D-Xylose & - & - & + & - \\
\hline $\mathrm{H}_{2} \mathrm{~S}$ production & + & + & - & + \\
\hline
\end{tabular}

Strains/species: 1, strain A3-108 ${ }^{\mathrm{T}} ; 2$, Marinirhabdus gelatinilytica $\mathrm{NH}^{\mathrm{T}} 3^{\mathrm{T}} ; 3$, Galbibacter mesophilus CGMCC $1.15663^{\mathrm{T}} ; 4$, Marixanthomonas ophiurae JCM $14121^{\mathrm{T}}$. All data were obtained from this study unless indicated. + positive; - negative

*Data were taken from Wu et al. (2016)

†Data were taken from Shams et al. (2007)

${ }^{\ddagger}$ Data were taken from Romanenko et al. (2007)
$15-40{ }^{\circ} \mathrm{C}$, and $0.5-10 \%(\mathrm{w} / \mathrm{v})$ on $\mathrm{MB}$. The growth of strain A3- $108^{\mathrm{T}}$ contained three phases, including the lag phase $(0-16 \mathrm{~h})$, exponential phase $(16-40 \mathrm{~h})$, and stationary phase (exceed $40 \mathrm{~h}$ ) at $30{ }^{\circ} \mathrm{C}$ on MB. The doubling time and the specific growth rate were $6.2 \mathrm{~h}$ and $0.16 \mathrm{~h}^{-1}$, respectively (Supplementary Fig. S2). Strain A3-108 ${ }^{\mathrm{T}}$ was positive for oxidase, arginine dihydrolase, nitrite reduction, and $\mathrm{H}_{2} \mathrm{~S}$ production. Carotenoid-type pigments were present but flexirubin-type pigments were not (Supplementary Fig. S3). Additional phenotypic properties are given in the species description, Tables 1, 3 and Supplementary Table S3. 


\section{Chemotaxonomic analysis}

The sole respiratory quinone detected in strain $\mathrm{A} 3-108^{\mathrm{T}}$ was menaquinone-6 (MK-6). Strain $\mathrm{A} 3-108^{\mathrm{T}}$ possessed phosphatidylethanolamine (PE), one unidentified aminophospholipid (APL), one unidentified aminolipid (AL) and one unidentified lipid (L1) as major polar lipids. In addition, two unidentified aminoglycolipids (AGL1-2), one unidentified glycolipid (GL), and two unidentified lipids (L2-3) were present as moderate or minor lipids (Supplementary Fig. S4). The major fatty acids of strain A3-108 ${ }^{\mathrm{T}}$ contained iso- $\mathrm{C}_{15: 0}(22.4 \%)$, iso- $\mathrm{C}_{17: 0} 3-\mathrm{OH}$ (17.2\%), iso- $\mathrm{C}_{15: 1} \mathrm{G}(15.7 \%)$, and summed feature $3\left(\mathrm{C}_{16: 1} \omega 7 c\right.$ and/or $\left.\mathrm{C}_{16: 1} \omega 6 c\right)(10.3 \%)$ (Table 2).

Table 2 Fatty acid composition (\%) of strain A3-108 ${ }^{\mathrm{T}}$ and its related taxa

\begin{tabular}{|c|c|c|c|c|}
\hline Fatty acid & 1 & 2 & 3 & 4 \\
\hline \multicolumn{5}{|l|}{ Straight-chain } \\
\hline $\mathrm{C}_{16: 0}$ & 2.5 & $\operatorname{tr}$ & 1.1 & 4.6 \\
\hline \multicolumn{5}{|l|}{ Unsaturated } \\
\hline $\mathrm{C}_{15: 1} \omega 6 c$ & - & - & 2.4 & 1.4 \\
\hline $\mathrm{C}_{17: 1} \omega 6 c$ & - & - & 1.2 & - \\
\hline $\mathrm{C}_{17: 1} \omega 8 c$ & - & - & $\operatorname{tr}$ & $\operatorname{tr}$ \\
\hline iso- $\mathrm{C}_{15: 1} \mathrm{G}$ & 15.7 & 7.3 & 7.8 & 3.2 \\
\hline iso- $\mathrm{C}_{16: 1} \mathrm{G}$ & 1.3 & $\operatorname{tr}$ & - & - \\
\hline \multicolumn{5}{|l|}{ Hydroxy } \\
\hline $\mathrm{C}_{15: 0} 2-\mathrm{OH}$ & 1.7 & $\operatorname{tr}$ & 1.3 & 1.2 \\
\hline $\mathrm{C}_{15: 0} 3-\mathrm{OH}$ & - & $\operatorname{tr}$ & 2.7 & - \\
\hline iso- $\mathrm{C}_{15: 0} 3-\mathrm{OH}$ & 3.1 & 6.1 & 10.3 & 3.3 \\
\hline iso- $\mathrm{C}_{16: 0} 3-\mathrm{OH}$ & 4.5 & 6.3 & 2.0 & 8.6 \\
\hline $\mathrm{C}_{16: 0} 3-\mathrm{OH}$ & $\operatorname{tr}$ & $\operatorname{tr}$ & $\operatorname{tr}$ & 1.1 \\
\hline $\mathrm{C}_{17: 0} 2-\mathrm{OH}$ & 5.7 & 1.0 & $\operatorname{tr}$ & 2.3 \\
\hline iso- $\mathrm{C}_{17: 0} 3-\mathrm{OH}$ & 17.2 & 26.3 & 28.1 & 17.3 \\
\hline \multicolumn{5}{|l|}{ Branched-chain } \\
\hline iso- $\mathrm{C}_{13: 0}$ & - & 1.3 & $\operatorname{tr}$ & - \\
\hline iso- $\mathrm{C}_{15: 0}$ & 22.4 & 35.8 & 11.5 & 22.0 \\
\hline anteiso- $\mathrm{C}_{15: 0}$ & 9.2 & 2.7 & $\operatorname{tr}$ & 3.2 \\
\hline anteiso- $\mathrm{C}_{15: 1} \mathrm{~A}$ & 2.3 & - & - & - \\
\hline iso- $\mathrm{C}_{16: 0}$ & 1.9 & 2.9 & $\operatorname{tr}$ & 8.7 \\
\hline iso- $\mathrm{C}_{16: 1} \mathrm{H}$ & - & - & 1.2 & 3.5 \\
\hline \multicolumn{5}{|l|}{ Summed feature* } \\
\hline 3 & 10.3 & 6.2 & 16.8 & 12.3 \\
\hline 9 & - & - & 8.5 & 4.6 \\
\hline
\end{tabular}

Strains/species: 1, strain A3-108 ${ }^{\mathrm{T}} ; 2$, Marinirhabdus gelatinilytica $\mathrm{NH}_{83}^{\mathrm{T}}$; 3, Galbibacter mesophilus CGMCC $1.15663^{\mathrm{T}}$; 4, Marixanthomonas ophiurae JCM $14121^{\mathrm{T}}$. All data were obtained from this study. Fatty acids representing less than $1.0 \%$ in all strains were omitted and the amounts $>10 \%$ were in bold. - Not detected, $\operatorname{tr}$ traces $(<1.0 \%)$

*Summed features represent groups of two fatty acids that could not be separated by GLC with the MIDI system. Summed feature 3 contained $\mathrm{C}_{16: 1} \omega 7 c$ and/or $\mathrm{C}_{16: 1} \omega 6 c$; Summed features 9 contained $\mathrm{C}_{16: 0}$ 10-methyl and/or iso- $\mathrm{C}_{17: 1} \omega 9 c$
Chemotaxonomic analysis supported the result of the phylogenetic analysis. The sole respiratory quinone detected in strain $\mathrm{A} 3-108^{\mathrm{T}}$ was consistent with members of the family Flavobacteriaceae (Bernardet 2015). The components iso- $\mathrm{C}_{17: 0} 3-\mathrm{OH}$ and iso- $\mathrm{C}_{15: 0}$ were major fatty acids in strain $\mathrm{A} 3-108^{\mathrm{T}}$ and the reference strains (Table 2). The presence of phosphatidylethanolamine (PE) was conserved in strain A $3-108^{\mathrm{T}}$ and the related genera (Table 3).

The chemotaxonomic results also showed some differences clearly in fatty acid compositions and polar lipid profiles between strain $\mathrm{A} 3-108^{\mathrm{T}}$ and the reference strains. The component iso- $\mathrm{C}_{15: 1} \mathrm{G}$ was presented as major fatty acid in the strain $\mathrm{A} 3-108^{\mathrm{T}}(15.7 \%)$, while it was presented as moderate fatty acid in Marinirhabdus gelatinilytica $\mathrm{NH}^{2} 3^{\mathrm{T}}$, Galbibacter mesophilus CGMCC $1.15663^{\mathrm{T}}$ and Marixanthomonas ophiurae JCM $14121^{\mathrm{T}}$ (3.2-7.8\%). In addition, the component anteiso- $\mathrm{C}_{15: 1}$ A was only detected in the strain A3-108 . In addition, the fatty acid of strain $\mathrm{A} 3-108^{\mathrm{T}}$ were different from the reference strains in the compositions and proportions (Table 2). With respect to polar lipid profiles, the component of the unidentified aminophospholipid (APL) was presented as major polar lipid in the strain $\mathrm{A} 3-108^{\mathrm{T}}$, while it was not presented in Galbibacter mesophilus CGMCC $1.15663^{\mathrm{T}}$. Besides, the unidentified aminolipid (AL), one of the major polar lipids, was not presented in the related strain Marixanthomonas ophiurae JCM $14121^{\mathrm{T}}$. In addition, moderate polar lipids, including an unidentified glycolipid (GL) and two aminoglycolipids (AGL1-2), were presented in the strain $\mathrm{A} 3-108^{\mathrm{T}}$, while they were not detected in the reference strains. Besides, lysophosphatidylethanolamine (LPE) and sphingolipid (SL) were only detected in Marixanthomonas ophiurae JCM $14121^{\mathrm{T}}$ (Supplementary Fig. S4 and Wu et al. 2016; Romanenko et al. 2007; Hameed et al. 2014).

\section{Conclusion}

Phylogenetic analysis indicated that the strain A3-108 ${ }^{\mathrm{T}}$ represented an independent lineage in family Flavobacteriaceae. Strain A3-108 ${ }^{\mathrm{T}}$ could be distinguished from the related genera and type strains of the family Flavobacteriaceae by phenotypic characteristics differences such as the range and optimum for growth of $\mathrm{NaCl}, \mathrm{pH}$ and temperature, enzyme activities, assimilation carbohydrates and acid production (Tables 1, 3). Based on the phylogenetic analysis, physiological, and chemotaxonomic characteristics, as well as genome analysis, strain $\mathrm{A} 3-108^{\mathrm{T}}$ represents a novel genus and species in the family Flavobacteriaceae, for which the name Luteirhabdus pelagi gen. nov., sp. nov. is proposed. 
Table 3 Differential properties of strain $\mathrm{A} 3-108^{\mathrm{T}}$ and its adjacent genera

\begin{tabular}{|c|c|c|c|c|c|c|}
\hline Characteristics & 1 & 2 & 3 & 4 & 5 & 6 \\
\hline Motility & NM & NM & $\mathrm{NM}$ & $\mathrm{NM}$ & NM & NM, GM \\
\hline Colony colour* & $\mathrm{Y}$ & $\mathrm{Y}, \mathrm{LY}$ & $\mathrm{Y}$ & $\mathrm{Y}$ & $\mathrm{Y}, \mathrm{PY}$ & Y, BY, YO, O, VOY \\
\hline Shape $^{\dagger}$ & $\mathrm{R}$ & $\mathrm{R}$ & $\mathrm{R}$ & $\mathrm{R}$ & $\mathrm{R}, \mathrm{C}$ & $\mathrm{R}, \mathrm{O}, \mathrm{F}$ \\
\hline $\begin{array}{l}\text { Temperature range } \\
\left({ }^{\circ} \mathrm{C}\right)\end{array}$ & $15-40$ & $4-38$ & $10-42$ & ND & $20-37$ & $-2-43$ \\
\hline $\begin{array}{l}\text { Optimum tempera- } \\
\text { ture }\left({ }^{\circ} \mathrm{C}\right)\end{array}$ & 28 & 30 & $25-32$ & $5-32$ & $28-30$ & $20-37$ \\
\hline $\mathrm{NaCl}$ range $(\%)$ & $0.5-10$ & $0.5-7.5$ & $0-9$ & $3.0-5.0$ & $0.5-5.5$ & $0-12$ \\
\hline Optimum $\mathrm{NaCl}(\%)$ & 1.0 & $2.0-5.0$ & $1.0-5.0$ & $1-12$ & 3 & $1-6$ \\
\hline $\mathrm{pH}$ range & $6.0-8.5$ & $4.0-8.5$ & NA & $6.5-8.5$ & $7.0-9.0$ & $5.0-10.0$ \\
\hline Optimum pH & 6.5 & 7.0 & NA & NA & 7.0 & $6.0-9.0$ \\
\hline Catalase & - & + & + & + & $\mathrm{v}$ & $\mathrm{v}$ \\
\hline Oxidase & + & - & + & + & - & $\mathrm{v}$ \\
\hline Hydrolysis of & & & & & & $\mathrm{v}$ \\
\hline CM-cellulose & - & NA & - & - & NA & - \\
\hline Esculin & - & + & + & - & NA & $\mathrm{v}$ \\
\hline Gelatin & + & + & + & + & + & $\mathrm{v}$ \\
\hline L-Tryosine & - & NA & NA & NA & NA & $\mathrm{v}$ \\
\hline Starch & - & - & + & - & - & $\mathrm{v}$ \\
\hline Tween 60 & - & + & NA & NA & NA & $\mathrm{v}$ \\
\hline Nitrate reduction & - & + & + & - & - & $\mathrm{v}$ \\
\hline $\mathrm{H}_{2} \mathrm{~S}$ production & + & - & NA & - & NA & $\mathrm{v}$ \\
\hline Major fatty acids ${ }^{\S}$ & $\begin{array}{l}\mathrm{I} 15: 1 \mathrm{G}, \mathrm{I} 17: 0 \mathrm{O} \\
\mathrm{I} 15: 0, \mathrm{SF} 3\end{array}$ & $\begin{array}{c}\text { I15:0, I15:1G, } \\
\text { A15:0, I16:0, } \\
\text { I17:0O, SF3 }\end{array}$ & $\begin{array}{l}\text { I15:0, I15:1, } \\
\text { I17:0O, SF3, } \\
\text { SF9 }\end{array}$ & $\begin{array}{l}\text { I16:0O, I17:0O, } \\
\text { A17:0O }\end{array}$ & $\begin{array}{l}\text { I17:0O, } \\
\text { I15:0, } \\
\text { I15:1G, } \\
\text { SF3 }\end{array}$ & 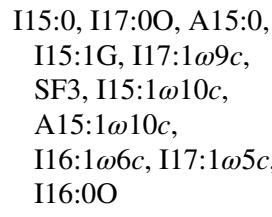 \\
\hline Major polar lipids ${ }^{\mathbb{I}}$ & PE, APL, AL, L & PE, APL, AL, L & $\mathrm{AL}, \mathrm{PE}, \mathrm{L}$ & $\begin{array}{l}\text { APL, PE, LPE, } \\
\text { SL, L }\end{array}$ & PE, AL, L & PE, L, AL, PL, PGL \\
\hline $\begin{array}{l}\text { DNA G }+\mathrm{C} \text { content } \\
(\% \text { or } \mathrm{mol} \%)\end{array}$ & 41.0 & $41.0-43.1$ & $37-38$ & 37.3 & $40.8-41.0$ & $33.0-48.7$ \\
\hline
\end{tabular}

Strains/species: 1, strain A3-108 ${ }^{\mathrm{T}}$ (this study); 2, Marinirhabdus (Wu et al. 2016; Yang et al. 2018); 3, Galbibacter (Li et al. 2013 ; Shams et al. 2007); 4, Marixanthomonas (Romanenko et al. 2007); 5, Aureisphaera (Yoon et al. 2015, 2016); 6, Aequorivita (Bowman 2002; Kim et al. 2010, 2018; Lin et al. 2015; Liu et al. 2013; Nedashkovskaya et al. 2003; Park et al. 2009, 2014; Rajasabapathy et al. 2015; Thevarajoo et al. 2016; Wang et al. 2020; Zhang et al. 2020). + positive, - negative, $v$ positive or negative, NA no data available

${ }^{\ddagger} N M$ non-motile, $G M$ gliding motility

* $Y$ yellow, $L Y$ lemon-yellow, $P Y$ pale-yellow, $B Y$ bright-yellow, $Y O$ yellow-orange, $O$ orange, $V O Y$ vivid orange yellow

${ }^{\dagger} R$ rod, $C$ coccus, $O$ ovoid, $F$ filaments

${ }^{\S} S F 3$ Summed feature 3, SF9 Summed feature 9, I15:0 iso- $\mathrm{C}_{15: 0}, I 15: 1 G$ iso- $\mathrm{C}_{15: 1}$ G, II7:0O iso-C $\mathrm{C}_{17: 0}$ 3-OH, I16:0 iso- $\mathrm{C}_{16: 0}, I 15: 1$ iso- $\mathrm{C}_{15: 1}$, I16:0O iso- $\mathrm{C}_{16: 0} 3-\mathrm{OH}, A 17: 00$ anteiso- $\mathrm{C}_{17: 0} 3-\mathrm{OH}, 16: 0 \mathrm{C}_{16: 0}, 18: 0 \mathrm{C}_{18: 0}$, A15:0 anteiso- $\mathrm{C}_{15: 0}, I 15: 0$ iso-C $\mathrm{C}_{15: 0}, I 17: 1 \omega 9 c$ iso-C $\mathrm{C}_{17: 1} \omega 9 c$, I17:1 $1 \omega 5 c$ iso-C 17: $1 \omega 5 c, I 15: 1 \omega 10 c$ iso- $\mathrm{C}_{15: 1} \omega 10 c, A 15: 1 \omega 10 c$ anteiso- $\mathrm{C}_{15: 1} \omega 10 c, 116: 1 \omega 6 c$ iso- $_{16: 1} \omega 6 c$

I $P E$ phosphatidylethanolamine, $A P L$ aminophospholipid, $A L$ aminolipid, $L$ lipid, $L P E$ lysophosphatidylethanolamine, $S L$ sphingolipid, $P L$ phospholipid, $P G L$ phosphoglycolipid

\section{Description of Luteirhabdus gen. nov.}

Luteirhabdus (Lu.te.i.rhab'dus. L. masc. adj. luteus yellow; Gr. fem. n. rhabdos rod; N.L. fem. n. Luteirhabdus a yellow rod-shaped bacterium).

Cells are Gram-stain-negative, strictly aerobic, nonmotile and rod-shaped. No flagellum was observed.
Carotenoid-type pigments are produced. Positive for oxidase, $\mathrm{H}_{2} \mathrm{~S}$ production. The predominant menaquinone is MK-6. Major polar lipids are phosphatidylethanolamine, one unidentified aminophospholipid, one unidentified aminolipid, and one unidentified lipid. The major cellular fatty acids are iso- $\mathrm{C}_{15: 0}$, iso- $\mathrm{C}_{17: 0} 3-\mathrm{OH}$, iso- $\mathrm{C}_{15: 1} \mathrm{G}$, and summed feature $3\left(\mathrm{C}_{16: 1} \omega 7 c\right.$ and/or $\left.\mathrm{C}_{16: 1} \omega 6 c\right)$. The DNA $\mathrm{G}+\mathrm{C}$ 
content of the type species is $41.0 \%$. The genus belongs to the family Flavobacteriaceae, class Flavobacteriia, phylum Bacteroidetes. The type species is Luteirhabdus pelagi.

\section{Description of Luteirhabdus pelagi sp. nov.}

Luteirhabdus pelagi (pe.la'gi. L. gen. n. pelagi of the open sea).

Cells are Gram-stain-negative, strictly aerobic, nonmotile, and rod-shaped with $0.5-0.8 \mu \mathrm{m}$ in width and 1.6-3.9 $\mu \mathrm{m}$ in length. Colonies are yellow, circular, convex, opaque, smooth, and 1-2 $\mathrm{mm}$ in diameter after 3 days of incubation at $30{ }^{\circ} \mathrm{C}$ on MA. Requires $\mathrm{Na}^{+}$ions for growth. Growth occurs in $\mathrm{NaCl}$-free $\mathrm{MB}$ supplement with $0.5-10 \%$ (w/v) $\mathrm{NaCl}$ (optimum at $1.0 \%$ ). The $\mathrm{pH}$ and temperature ranges for growth are $\mathrm{pH} 6.0-8.5$ and $15-40{ }^{\circ} \mathrm{C}$ (optimum at pH 6.5 and $28^{\circ} \mathrm{C}$ ). Carotenoid-type pigments are produced but flexirubin-type pigments are not. No anaerobic growth occurs on MA supplemented with sodium nitrate, sodium sulfate, and sodium thiosulfate. Positive for oxidase, arginine dihydrolase, gelatin, and nitrite reduction. Negative for catalase, indole production, glucose fermentation, urease, and nitrate reduction. Negative for the degradation of Tweens 40, Tweens 60, L-Tryosine, starch, esculin, CM-cellulose, DNA, and $\beta$-galactosidase. $\mathrm{H}_{2} \mathrm{~S}$ production occurs on $\mathrm{MB}$ supplemented with sodium thiosulfate, cysteine and sodium sulfate. Acid and alkaline phosphatase, $\alpha$-chymotrypsin, cystine arylamidase, esterase (C4), esterase lipase (C8), leucine arylamidase, naphthol-AS-BI-phosphohydrolase, trypsin and valine arylamidase activities are present. Acid is not produced from citrate, D-cellobiose, D-fructose, D-galactose, D-glucose, D-maltose, D-mannose, D-salicin, D-trehalose, D-xylose, L-arabinose, L-malate, L-glutamic acid, and sucrose. The principal fatty acids are iso- $\mathrm{C}_{15: 0}$, iso- $\mathrm{C}_{17: 0}$ 3- $\mathrm{OH}$, iso- $\mathrm{C}_{15: 1} \mathrm{G}$, and summed feature $3\left(\mathrm{C}_{16: 1} \omega 7 c\right.$ and/or $\left.\mathrm{C}_{16: 1} \omega 6 c\right)$. The sole respiratory quinone is menaquinone-6 (MK-6). The major polar lipids are phosphatidylethanolamine, one unidentified aminophospholipid, one unidentified aminolipid, and one unidentified lipid. In addition, moderate to minor amounts of two unidentified aminoglycolipids, one unidentified glycolipid, and two unidentified lipids are present. The DNA G $+\mathrm{C}$ content is $41.0 \%$ (by genome).

The type strain A3-108 ${ }^{\mathrm{T}}\left(\right.$ CGMCC $1.18821^{\mathrm{T}}=\mathrm{KCTC}$ $82563^{\mathrm{T}}$ ) is isolated from the seawater, collected from the West Pacific Ocean (at depth of $300 \mathrm{~m}, 23.2^{\circ} \mathrm{N}, 162.3^{\circ} \mathrm{E}$ ). The GenBank/EMBL/DDBJ accession number for the $16 \mathrm{~S}$ rRNA gene sequence of strain A3-108 ${ }^{\mathrm{T}}$ is MW244395 and the GenBank accession number for the whole genome sequence is JAECMS000000000.

Supplementary Information The online version contains supplementary material available at https://doi.org/10.1007/s00203-021-02557-3.
Acknowledgements The authors would like to thank the whole staff and researchers participated in investigation for the research vessel DA YANG YI HAO.

Author contributions YW and PZ conceived and designed the experiments. WR and LG performed the experiments. WR, PZ, and XX analyzed the data. FM and LS contributed reagents/materials/analysis tools. WR and YW wrote the paper.

Funding China Ocean Mineral Resources and D Association (COMRA) Special Foundation under contract No. DY135-B2-10; the Scientific Research fund of the Second Institute of Oceanography, MNR under contract No. JG1527 and JG1524; the National Natural Science Foundation of China under contract No. 41876182, and Global Change and Air-sea interaction II.

Availability of data and material The GenBank/EMBL/DDBJ accession number for the $16 \mathrm{~S}$ rRNA gene sequence of strain $\mathrm{A} 3-108^{\mathrm{T}}$ is MW244395. The GenBank accession numbers for the whole genome sequence of strain $\mathrm{A} 3-108^{\mathrm{T}}$ and Galbibacter mesophilus CGMCC $1.15663^{\mathrm{T}}$ are JAECMS000000000 and JAERQH000000000, respectively.

\section{Declarations}

Conflict of interest The authors declare that there are no conflicts of interest.

Open Access This article is licensed under a Creative Commons Attribution 4.0 International License, which permits use, sharing, adaptation, distribution and reproduction in any medium or format, as long as you give appropriate credit to the original author(s) and the source, provide a link to the Creative Commons licence, and indicate if changes were made. The images or other third party material in this article are included in the article's Creative Commons licence, unless indicated otherwise in a credit line to the material. If material is not included in the article's Creative Commons licence and your intended use is not permitted by statutory regulation or exceeds the permitted use, you will need to obtain permission directly from the copyright holder. To view a copy of this licence, visit http://creativecommons.org/licenses/by/4.0/.

\section{References}

Aziz RK, Bartels D, Best AA et al (2008) The RAST server: rapid annotations using subsystems technology. BMC Genom 8(9):75

Barco RA, Garrity GM, Scott JJ et al (2020) A genus definition for bacteria and archaea based on a standard genome relatedness index. Mbio 11(1):e02475-e2519

Bernardet JF (2002) Proposed minimal standards for describing new taxa of the family Flavobacteriaceae and emended description of the family. Int J Syst Evol Microbiol 52(3):1049-1070

Bernardet JF (2015) Flavobacteriaceae. In: Trujillo ME, Dedysh S, DeVos P, Hedlund B, Kämpfer P, Rainey FA, Whitman WB (eds) Bergey's manual of systematics of archaea and bacteria. Wiley, Chichester

Bernardet JF, Segers P, Vancanneyt M et al (1996) Cutting a gordian knot: emended classification and description of the genus Flavobacterium, emended description of the family Flavobacteriaceae, and proposal of Flavobacterium hydatis nom. nov. (basonym, Cytophaga aquatilis Strohl and Tait 1978). Int J Syst Evol Microbiol 46(1):128-148 
Boehlert GW, Genin A (1987) A review of the effects of seamounts on biological processes. Seamounts Islands Atolls 43:319-334

Bowman JP (2002) Aequorivita gen. nov., a member of the family Flavobacteriaceae isolated from terrestrial and marine Antarctic habitats. Int J Syst Evol Microbiol 52:1533-1541

Brown RC, Hopps HC (1973) Staining of bacteria in tissue sections: a reliable gram stain method. Am J Clin Pathol 60(2):234-240

Capella-Gutiérrez S, Silla-Martínez JM, Gabaldón T (2009) TrimAl: a tool for automated alignment trimming in large-scale phylogenetic analyses. Bioinformatics 25(15):1972-1973

Chun J, Lee I, Kim YO et al (2016) OrthoANI: an improved algorithm and software for calculating average nucleotide identity. Int J Syst Evol Microbiol 66(2):1100-1103

Clark MR, Rowden AA, Schlacher T et al (2010) The ecology of seamounts: structure, function, and human impacts. Ann Rev Mar Sci 2(1):253-278

Dong XZ, Cai MY (2001) Determinative manual for routine bacteriology. Scientific Press, Beijing

Fautz E, Reichenbach H (1980) A simple test for flexirubin-type pigments. FEMS Microbiol Lett 8(2):87-91

Felsenstein J (1981) Evolutionary trees from DNA sequences: a maximum likelihood approach. J Mol Evol 17(6):368-376

Fitch WM (1971) Toward defining the course of evolution: minimum change for a specific tree topology. Syst Zool 20(4):406-416

García-López M, Meier-Kolthoff JP, Tindall BJ et al (2019) Analysis of 1,000 type-strain genomes improves taxonomic classification of Bacteroidetes. Front Microbiol 23(10):2083

Hameed A, Shahina M, Lin SY et al (2014) Robertkochia marina gen. nov., sp. nov., of the family Flavobacteriaceae, isolated from surface seawater, and emended descriptions of the genera Joostella and Galbibacter. Int J Syst Evol Microbiol 64(Pt2):533-539

Hildebrand DC, Palleroni NJ, Hendson M et al (1994) Pseudomonas flavescens sp. nov., isolated from Walnut Blight Cankers. Int J Syst Evol Microbiol 44(3):410-415

Jooste PJ (1985) The taxonomy and significance of FlavobacteriumCytophaga strains from dairy sources. Dissertation, University of the Orange Free State Bloemfontein

Kanehisa M, Sato Y, Kawashima M et al (2016) KEGG as a reference resource for gene and protein annotation. Nucleic Acids Res 44(D1):D457-462

Katoh K, Standley DM (2013) MAFFT multiple sequence alignment software version 7: improvements in performance and usability. Mol Biol Evol 30(4):772-780

Kim BS, Kim OS, Moon Y et al (2010) Vitellibacter aestuarii sp. nov., isolated from tidal-flat sediment, and an emended description of the genus Vitellibacter. Int J Syst Evol Microbiol 60:1989-1992

Kim HC, Kim YO, Park S et al (2018) Vitellibacter todarodis sp. nov., isolated from intestinal tract of a squid (Todarodes pacificus). Int J Syst Evol Microbiol 68:1233-1237

Kimura M (1980) A simple method for estimating evolutionary rates of base substitutions through comparative studies of nucleotide sequences. J Mol Evol 16(2):111-120

Komagata K, Susuki K (1987) Lipid and cell-wall analysis in bacterial systematics. Method Microbiol 19:161-207

Konstantinidis KT, Tiedje JM (2005) Towards a genome-based taxonomy for prokaryotes. J Bacteriol 187(18):6258-6264

Kumar S, Stecher G, Tamura K (2016) MEGA7: molecular evolutionary genetics analysis version 7.0 for bigger datasets. Mol Biol Evol 33(7):1870-1874

Lagesen K, Hallin P, Rodland EA et al (2007) RNAmmer: consistent and rapid annotation of ribosomal RNA genes. Nucleic Acids Res 35(9):3100-3108

Lechner M, Hernandez-Rosales M, Doerr D et al (2014) Orthology detection combining clustering and synteny for very large datasets. PLoS ONE 9(8):e105015
Leifson E (1963) Determination of carbohydrate merabolism of marine bacteria. J Bacteriol 85(5):1183-1184

Li C, Lai Q, Fu Y et al (2013) Galbibacter marinus sp. nov., isolated from deep-sea sediment. Int J Syst Evol Microbiol 63:1427-1430

Lin SY, Hameed A, Wen CZ et al (2015) Vitellibacter echinoideorum sp. nov., isolated from a sea urchin (Tripneustes gratilla). Int J Syst Evol Microbiol 65:2320-2325

Liu JJ, Zhang XQ, Pan J et al (2013) Aequorivita viscosa sp. nov., isolated from an intertidal zone, and emended descriptions of Aequorivita antarctica and Aequorivita capsosiphonis. Int J Syst Evol Microbiol 63:192-3196

Luis M, Rodriguez-R LM, Konstantinos TK (2014) Bypassing cultivation to identify bacterial species. Microbe 9(3):111-118

Luo R, Liu B, Xie Y et al (2012) Erratum: SOAPdenovo2: an empirically improved memory-efficient short-read de novo assembler. Gigascience 1(1): 18

Luo C, Rodriguez-R LM, Konstantinidis KT (2014) MyTaxa: an advanced taxonomic classifier for genomic and metagenomic sequences. Nucleic Acids Res 42(8):e73

Mashayek A, Ferrari R, Merrifield S et al (2017) Topographic enhancement of vertical turbulent mixing in the Southern Ocean. Nat Commun 6(8): 14197

Meier-Kolthoff JP, Auch AF, Klenk HP et al (2013) Genome sequencebased species delimitation with confidence intervals and improved distance functions. BMC Bioinform 14(60):1471-2105

Monod J (1949) The growth of bacterial cultures. Annu Rev Microbiol 3(1):371-394

Muck S, Griessler T, Köstner N et al (2014) Fracture zones in the Mid Atlantic Ridge lead to alterations in prokaryotic and viral parameters in deep-water masses. Front Microbiol 2(5):264

Nedashkovskaya OI, Suzuki M, Vysotskii MV et al (2003) Vitellibacter vladivostokensis gen. nov., sp. nov., a new member of the phylum Cytophaga-Flavobacterium-Bacteroides. Int J Syst Evol Microbiol 53:1281-1286

Nguyen LT, Schmidt HA, von Haeseler A et al (2015) IQ-TREE: a fast and effective stochastic algorithm for estimating maximumlikelihood phylogenies. Mol Biol Evol 32(1):268-274

Park SC, Baik KS, Kim MS et al (2009) Aequorivita capsosiphonis sp. nov., isolated from the green alga Capsosiphon fulvescens, and emended description of the genus Aequorivita. Int J Syst Evol Microbiol 59:724-728

Park S, Lee KC, Bae KS et al (2014) Vitellibacter soesokkakensis sp. nov., isolated from the junction between the ocean and a freshwater spring and emended description of the genus Vitellibacter. Int J Syst Evol Microbiol 64:588-593

Parks DH, Imelfort M, Skennerton CT et al (2015) CheckM: assessing the quality of microbial genomes recovered from isolates, single cells, and metagenomes. Genome Res 25(7):1043-1055

Polzin KL, Toole M, Ledwell JR et al (1997) Spatial variability of turbulent mixing in the abyssal ocean. Science 276(5309):93-96

Pruesse E, Quast C, Knittel K et al (2007) SILVA: a comprehensive online resource for quality checked and aligned ribosomal RNA sequence data compatible with ARB. Nucleic Acids Res 35(21):7188-7196

Qin YS, Yin H (2011) Western Pacific: the strategic priority in China deep sea research. Adv Earth Sci 26(3):245-248

Rajasabapathy R, Mohandass C, Yoon JH et al (2015) Vitellibacter nionensis sp. nov., isolated from a shallow water hydrothermal vent. Int J Syst Evol Microbiol 65:692-697

Reichenbach H (1992) The Order Cytophagales. In: Balows A, Trüper HG, Dworkin M, Harder W, Schleifer KH (eds) The prokaryotes. Springer, New York, pp 549-590 
Richter M, Rosselló-Móra R (2009) Shifting the genomic gold standard for the prokaryotic species definition. Proc Natl Acad Sci USA 106(45):19126-19131

Richter M, Frank OG, Ramon RM et al (2016) JSpeciesWS: a web server for prokaryotic species circumscription based on pairwise genome comparison. Bioinformatics 32(6):929-931

Romanenko LA, Uchino M, Frolova GM et al (2007) Marixanthomonas ophiurae gen nov, sp nov, a marine bacterium of the family Flavobacteriaceae isolated from a deep-sea brittle star. Int J Syst Evol Microbiol 57(Pt 3):457-462

Saitou N, Nei M (1987) The neighbor-joining method: a new method for reconstructing phylogenetic trees. Mol Biol Evol 4(4):406-425

Sasser M (1990) Identification of bacteria by gas chromatography of cellular fatty acids. In: MIDI technical note 101. MIDI inc, Newark

Seemann T (2014) Prokka: rapid prokaryotic genome annotation. Bioinformatics 30(14):2068-2069

Shams TK, Yasuyoshi N, Shigeaki H (2007) Galbibacter mesophilus gen. nov., sp. nov., a novel member of the family Flavobacteriaceae. Int J Syst Evol Microbiol 57(Pt 5):969-973

Thevarajoo S, Selvaratnam C, Goh KM et al (2016) Vitellibacter aquimaris sp. nov., a marine bacterium isolated from seawater. Int J Syst Evol Microbiol 66:3662-3668

Thomson JD, Higgins DG, Gibson TJ (1994) CLUSTALW: improving the sensitivity of progressive multiple sequence alignment through sequence weighting, position-specific gap penalties and weight matrix choice. Nucleic Acids Res 22:4673-4680

Tindall BJ, Sikorski J, Smibert RA et al (2007) Phenotypic characterization and the principles of comparative systematics. In: Reddy CA, Beveridge TJ, Breznak JA, Marzluf GA, Schmidt TM, Snyder LR (eds) Methods for general and molecular microbiology, 3rd edn. American Society for Microbiology, Washington DC, pp 330-393

Wang Q, Cai SD, Liu J et al (2020) Aequorivita sinensis sp. nov., isolated from sediment of the East China Sea, and reclassification of Vitellibacter todarodis as Aequorivita todarodis comb. nov. and Vitellibacter aquimaris as Aequorivita aquimaris comb. nov. Int J Syst Evol Microbiol 70:3323-3327
Wayne LG, Brenner DJ, Colwell RR et al (1987) Report of the Ad Hoc committee on reconciliation of approaches to bacterial systematics. Int J Syst Bacteriol 37(4):463-464

Wolfe AJ, Berg HC (1989) Migration of bacteria in semisolid agar. Proc Natl Acad Sci USA 86(18):6973-6977

Wu YH, Xamxidin M, Meng FX et al (2016) Marinirhabdus gelatinilytica gen. nov., sp. nov., isolated from seawater. Int J Syst Evol Microbiol 66(8):3095-3101

Yang SH, Oh JH, Seo HS et al (2018) Marinirhabdus citrea sp. nov., a marine bacterium isolated from a seaweed. Int J Syst Evol Microbiol 68:547-551

Yesson C, Clark MR, Taylor ML et al (2011) The global distribution of seamounts based on 30 arc seconds bathymetry data. Deep-Sea Res PT I 58(4):442-453

Yoon J, Yasumoto-Hirose M, Kasai H (2015) Aureisphaera galaxeae gen. nov., sp. nov., a marine member of the family Flavobacteriaceae isolated from the hard coral Galaxea fascicularis. Anton Leeuw Int J G 107:1379-1386

Yoon J, Adachi K, Kasai H (2016) Aureisphaera salina sp. nov., a member of the family Flavobacteriaceae isolated from an ascidian. Int J Syst Evol Microbiol 66:2999-3004

Yoon SH, Ha SM, Kwon S et al (2017) Introducing EzBioCloud: a taxonomically united database of 16S rRNA gene sequences and whole-genome assemblies. Int J Syst Evol Microbiol 67(5):1613-1617

Zhang S, Zhou H, Sun $\mathrm{C}$ et al (2020) $e$ sp. nov., a novel bacterium isolated from the estuarine sediment of the Pearl River in China, and transfer of Vitellibacter todarodis and Vitellibacter aquimaris to the genus Aequorivita as Aequorivita todarodis comb. nov. and Aequorivita aquimaris comb. nov. Int J Syst Evol Microbiol 70:3117-3122

Publisher's Note Springer Nature remains neutral with regard to jurisdictional claims in published maps and institutional affiliations. 